\title{
Macular sparing investigated by means of Haidinger brushes
}

\author{
M. T. PERENIN ${ }^{1}$ AND E. VADOT ${ }^{2}$ \\ ${ }^{1}$ Laboratoire de Neuropsychologie Expérimentale, Unité 94-INSERM, 16 avenue du Doyen Lépine, \\ 69500 Bron, France, and the ${ }^{2}$ Clinique Ophtalmologique Universitaire, Hôpital Edouard Herriot- \\ Pavillon C, 69003 Lyon, France
}

SUMmARY Haidinger brushes, an entoptic phenomenon perceived only through the most central macular retina, have been used in addition to kinetic and static perimetry with the Tubingen perimeter for determining macular sparing and splitting in hemianopic patients. Seven patients were examined: 2 with a bitemporal hemianopia resulting from traumatic damage to the optic chiasma, and 5 with a homonymous hemianopia resulting from extensive lesions of the optic radiations and/or the occipital cortex (including 2 cases of hemidecortication). On perimetric examination some exceptions could be observed in the correspondence of macular splitting and sparing respectively with pre- and postgeniculate lesions, but this was not the case when Haidinger brushes were used. Half of the figure was then perceived by the patients with lesions of the chiasma and the entire figure by all the patients with geniculostriate lesions. We consider that results obtained by this simple method are more reliable than those obtained by perimetry and that Haidinger brushes should be used for macular field examination in neuro-ophthalmic practice.

The problem of 'macular sparing' in hemianopic visual fields has been debated for many years but still remains an enigma. The topographical value, the anatomo-functional substrates, and even the reality of the phenomenon itself have been, and still are, questioned.

Macular sparing commonly designates the spared vision of the most central area of an otherwise blind hemifield, with the aspect of a $3^{\circ}$ to $4^{\circ}$ bulging of preserved field away from the midline. Some authors have considered such bulging to be the definitive characteristic of 'true macular sparing'. 'False macular sparing', in contrast was the term used by the same authors for an apparent residue of vision in a strip $3^{\circ}$ to $4^{\circ}$ wide along the vertical meridian. In the latter case the overshot visual field was always attributed to eccentric or unstable fixation.

Macular sparing is usually seen as a result of a postgeniculate lesion involving the visual cortex, though absence of sparing, 'macular splitting,' does not mean that the lesion is necessarily pregeniculate. ${ }^{2}$ In large series of tumoral ${ }^{34}$ or traumatic ${ }^{56}$ lesions involving the occipital cortex both figures (sparing and splitting) were seen to be represented, but macular splitting was always observed in a minority of cases. Williams and Gassel ${ }^{1}$ never found

Correspondence to Dr Marie-Thèrése Perenin. sparing in cases with surgical extirpation of the visual cortex. Such arguments have favoured the hypothesis that macular sparing results from incomplete occipital lesions. Since the blood supply is from the middle cerebral artery, enlarged representation of the central visual field in the striate cortex would indeed increase the probability of central field sparing in such cases.

However, in a more recent study using carefully controlled perimetry (including static perimetry with the Tubingen perimeter) $\mathrm{Huber}^{7}$ constantly found some preserved central field in patients with occipital lobectomy. In most cases it extended about $1^{\circ}$ or less into the hemianopic side, which he referred to as 'foveolar' sparing. A similar extent of spared central field (averaging $1.5^{\circ}$ ) was also observed by Koerner and Teuber ${ }^{8}$ in most of their cases of occipital head injuries, extensively tested with the Tubingen perimeter. But these authors also found 1 clear case of macular splitting by a small scotoma which reached the fixation point, a possibility previously pointed out by Spalding. ${ }^{5}$

Anatomical findings have been recently obtained which are also relevant to the problem of macular sparing. A nasotemporal overlap (of about $1^{\circ}$ ) of the retinogeniculate fibres across the vertical meridian has been demonstrated in monkeys, ${ }^{910}$ providing concrete proof of the hypothesis ${ }^{11}$ of a bilateral representation of the fovea on the visual cortex. 
Table 1 Summarised case histories of the patients.

\begin{tabular}{|c|c|c|c|c|c|c|c|c|}
\hline \multirow[b]{2}{*}{ Cases } & \multirow{2}{*}{$\begin{array}{c}\text { Age } \\
(y r)\end{array}$} & \multirow{2}{*}{ Sex } & \multirow{2}{*}{$\begin{array}{l}\text { Time elapsed } \\
\text { from lesion } \\
(y r)\end{array}$} & \multirow{2}{*}{ History and description of lesion } & \multicolumn{2}{|c|}{ Visual acuity } & \multirow{2}{*}{$\begin{array}{l}\text { Fixation } \\
\text { (ophthalmo- } \\
\text { scopic } \\
\text { examination) }\end{array}$} & \multirow[b]{2}{*}{ Visual field } \\
\hline & & & & & $\begin{array}{l}\text { Right } \\
\text { eye }\end{array}$ & $\begin{array}{l}\text { Left } \\
\text { eye }\end{array}$ & & \\
\hline 1 & 15 & $\mathbf{M}$ & 2 & $\begin{array}{l}\text { Anterior frontal gun shot injury with } \\
\text { osteomeningeal break. Removal of } \\
\text { the bullet just above the optic } \\
\text { chiasma, which appeared severely } \\
\text { damaged }\end{array}$ & $5 / 10$ & $9 / 10$ & $\begin{array}{l}\text { Parafoveal } \\
\text { temporal } \\
\text { fixation about } \\
2^{\circ} \text { on RE, } 1^{\circ} \\
\text { on LE }\end{array}$ & $\begin{array}{l}\text { Bitemporal hemianopia. } \\
\text { Macular splitting on LE. } \\
2^{\circ} \text { macular sparing and } \\
1-3^{\circ} \text { strip of overshot field } \\
\text { on RE }\end{array}$ \\
\hline 2 & 21 & $\mathbf{M}$ & 2 & $\begin{array}{l}\text { Anterior frontal traumatism and } \\
\text { fracture. Operation for osteomenin- } \\
\text { geal break with extended wound of } \\
\text { the dura mater up to the sella } \\
\text { tursica, optic chiasma damaged }\end{array}$ & $10 / 10$ & $8 / 10$ & $\begin{array}{l}\text { Foveal on both } \\
\text { eyes }\end{array}$ & $\begin{array}{l}\text { Bitemporal hemianopia. } \\
\text { Macular splitting on both } \\
\text { eyes. Overshot sector of } \\
\text { about } 5^{\circ} \text { in the upper } \\
\text { quadrant of RE }\end{array}$ \\
\hline 3 & 17 & $\mathbf{F}$ & $2 \cdot 5$ & $\begin{array}{l}\text { Angioma in the territory of the left } \\
\text { posterior cerebral artery (PCA). } \\
\text { Parasagittal incision of the } \\
\text { posterior temporal cortex. Ligature } \\
\text { of the PCA. Resection of the whole } \\
\text { malformation }\end{array}$ & $10 / 10$ & $10 / 10$ & $\begin{array}{l}\text { Foveal on both } \\
\text { eyes }\end{array}$ & $\begin{array}{l}\text { Left homonymous hemia- } \\
\text { nopia. Less than } 1^{\circ} \\
\text { macular sparing on both } \\
\text { eyes. Overshot sector of } \\
\text { about } 5^{\circ} \text { in the lower } \\
\text { quadrant of RE }\end{array}$ \\
\hline 4 & 25 & $\mathbf{F}$ & $1 \cdot 4$ & $\begin{array}{l}\text { Left occipital angioma. Ligature of } \\
\text { the most proximal branch of the } \\
\text { PCA. Incision of the occipital } \\
\text { cortex at } 2 \mathrm{~cm} \text { from the occipital } \\
\text { pole. Resection of a paraven- } \\
\text { tricular haematoma and resection } \\
\text { of the lesion }\end{array}$ & $10 / 10$ & $10 / 10$ & $\begin{array}{l}\text { Slightly } \\
\text { unstable, } \\
\text { parafoveal } \\
\text { fixation about } \\
1^{\circ} \text { temporal } \\
\text { on RE and } \\
\text { nasal on LE }\end{array}$ & $\begin{array}{l}\text { Right homonymous hemia- } \\
\text { nopia. } 0.5^{\circ} \text { (RE) and } 1.5^{\circ} \\
\text { (LE) macular sparing } \\
\text { Overshot strip of } 0.5-1.5^{\circ} \\
\text { on both eyes }\end{array}$ \\
\hline 5 & 19 & $\mathbf{M}$ & 19 & $\begin{array}{l}\text { Right hemicorporal epileptic seizures } \\
\text { at } 3 \text { months, one generalised seizure } \\
\text { at } 12 \text { yr. Right homonymous } \\
\text { hemianopia discovered on a } \\
\text { systematic examination at } 18 \mathrm{yr} \text {. } \\
\text { CT scan: large porencephalic cyst } \\
\text { of the whole left occipital lobe }\end{array}$ & $10 / 10$ & $8 / 10$ & $\begin{array}{l}\text { Unstable, often } \\
\text { parafoveal } \\
\text { fixation (up } \\
\text { to } 1-2^{\circ} \\
\text { temporal on } \\
\text { RE and nasal } \\
\text { on LE) }\end{array}$ & $\begin{array}{l}\text { Right homonymous hemia- } \\
\text { nopia. Macular sparing of } \\
4-6^{\circ} \text { on both eyes. } \\
\text { Overshot strip of } 3-4^{\circ} \text { on } \\
\text { both eyes. }\end{array}$ \\
\hline 6 & 21 & $\mathbf{M}$ & 14 & $\begin{array}{l}\text { Neonatal anoxia. Infantile hemiplegia- } \\
\text { epilepsy. Left hemidecortication for } \\
\text { intractable seizures at the age of } 7\end{array}$ & $10 / 10$ & $9 / 10$ & $\begin{array}{l}\text { Foveal fixation } \\
\text { on RE, un- } \\
\text { stable fixation } \\
\text { which could } \\
\text { be shifted up } \\
\text { to about } 2^{\circ} \\
\text { nasal on LE }\end{array}$ & $\begin{array}{l}\text { Right homonymous hemia- } \\
\text { nopia. } 3-5^{\circ} \text { macular } \\
\text { sparing on both eyes. Over } \\
\text { shot strip of } 2-3^{\circ} \text { on both } \\
\text { eyes }\end{array}$ \\
\hline 7 & 13 & $\mathbf{F}$ & 6 & $\begin{array}{l}\text { Infantile hemiplegia. EEG epileptic } \\
\text { discharges. Removal of } 2 \text { right } \\
\text { porencephalic cysts (temporal and } \\
\text { frontal) and temporal lobectomy at } \\
\text { the age of } 2 \text {. Right hemidecortication } \\
\text { at the age of } 7\end{array}$ & $8 / 10$ & $4 / 10$ & $\begin{array}{l}\text { Unstable } \\
\text { fixation } \\
\text { which could } \\
\text { be shifted up } \\
\text { to about } 2^{\circ} \\
\text { nasal on RE, } \\
2-3^{\circ} \text { temporal } \\
\text { on LE }\end{array}$ & $\begin{array}{l}\text { Left homonymous hemia- } \\
\text { nopia. } 3-4^{\circ} \text { macular } \\
\text { sparing on both eyes. } \\
\text { Overshot strip of } 2-3^{\circ} \text { on } \\
\text { both eyes }\end{array}$ \\
\hline
\end{tabular}

We believed that a complementary way of studying macular sparing to find answers to some of the above questions would be to use entoptic phenomena such as Haidinger brushes, which can be perceived only through the most central macular retina. This technique would avoid errors encountered in even the best perimetric techniques, such as those due to slightly unstable fixation. Haidinger brushes and also the Maxwell spot, another entoptic phenomenon, have been previously used in a case of traumatic bitemporal hemianopia. ${ }^{12}$ Splitting of the macula was demonstrated in this case by the fact that the patient saw only one half of either of these figures.

In the present study Haidinger brushes were used, in addition to dynamic and static perimetry with the
Tubingen perimeter, for investigating the central macular field of hemianopic patients with either pregeniculate (chiasmatic) or postgeniculate lesions of the central visual pathways. Preliminary results have been previously reported. ${ }^{13}$

\section{Material and methods}

\section{SUBJECTS}

Two subjects with pregeniculate and 5 with postgeniculate lesions were tested. They were all selected for completeness (vertical midline not considered) of their hemianopic deficit on preliminary Goldmann perimetric examination. Their case histories are summarised in Table 1.

The 2 patients with pregeniculate lesions had 
similar histories of anterior frontal injury with damage to the dura mater up to the sella tursica which had necessitated surgical operation. A fragment of bone in case 2 and a rifle bullet in case 1 had been removed from near the optic chiasma, which was seen to be severely damaged in both cases.

Two of the patients with postgeniculate lesions (cases 3 and 4) had been operated on for the ablation of an occipital angioma. This had required a small resection of the occipital pole in case 4 and the ligature of the posterior cerebral artery in both cases. Case 5 had had from the first months of life a porencephalic cyst which appeared on a CT scan to extend over the whole posterior third of the left cerebral hemisphere. The last 2 patients, cases 6 and 7 , had undergone respectively a left and a right hemidecortication at the age of 7 years for intractable epilepsy associated with infantile hemiplegia. All 5 patients showed some degree of residual vision, at least for locating targets within their perimetrically blind field. Results on this topic have been previously published for cases 6 and 7.14 15

\section{PERIMETR Y}

The Tubingen perimeter ${ }^{16} 17$ was used for both dynamic and static perimetry, the background luminance being always set at the same mesopic level $\left(10 \mathrm{asb}\right.$, i.e., $\left.3 \cdot 18 \mathrm{~cd} / \mathrm{m}^{2}\right) .90^{\circ}$ kinetic perimetry was performed with a spot of maximum size (116 $)$ and luminance $\left(318 \mathrm{~cd} / \mathrm{m}^{2}\right), 30^{\circ}$ kinetic and static perimetry with a $10^{\prime}$ spot of different juxtaliminar luminance. An ascending method of limits was used for static perimetry, target luminance being raised by $0.1 \mathrm{log}$ unit steps. Differential thresholds were thus measured serially in $2^{\circ}$ or $5^{\circ}$ steps along the horizontal meridian in each subject, from centre to periphery in the normal and then in the hemianopic field.

\section{HAIDINGER BRUSHES}

This entoptic phenomenon, first described by Haidinger in $1844,{ }^{18}$ can be seen when looking through a polarised filter at a uniform blue field such as the sky: it consists of a faint, yellow and dark blue figure resembling an hourglass or a double brush (Fig. 1) subtending an angle of about $3^{\circ}$, centered on the fixation point (and therefore seen to move with displacement of the fixation point). It quickly fades

Fig. 1 Drawing of Haidinger brushes. Apparent length is about $3^{\circ}$. unless the orientation of the polarising light change by rotating the polarising filter. This produces a permanent figure rotating around its centre. The phenomenon is generally attributed to the selective absorption of the blue light by the yellow pigment of the macula lutea contained in the Henle fibres. The radial orientation of these fibres, and perhaps also of the pigment molecules, could be responsible for the radial dichroism which gives rise to the maximum absorption occurring along a diameter perpendicular to the polarisation plane of the incident light. This would account for the shape of the Haidinger figure, which is perceived only in the most central part of the macular field, that is, the part corresponding to maximum density of the yellow pigment. ${ }^{19} 20 \mathrm{~A}$ similar polarisation phenomenon has been demonstrated by photographing the polarised light reflected from a monkey's retina; a picture resembling Haidinger brushes was obtained.21

Haidinger brushes are currently elicited in orthoptic practice by a Cüpper's co-ordinator. That apparatus was used in the present study. For all patients each eye was exposed successively to the polarised light, while the polariser filter inside the apparatus was rotated at moderate speed. The patient either was free to let his gaze wander over the blue field or had to fixate a small black point at the edge of a white cardboard masking either the normal or the hemianopic part of his visual field. At each stage he had to describe verbally or to draw what he saw. The picture of Fig. 1 or the photographs taken from Hochheimer's paper were shown to him for comparison.

\section{Results}

\section{PERIMETRIC DATA}

Patients with pregeniculate lesions. Both patients with lesion of the optic chiasma had a nearly complete, dense, bitemporal hemianopia on $90^{\circ}$ kinetic perimetry. On $30^{\circ}$ kinetic and static perimetry there was a macular splitting in the left eye of case 1 and in both eyes in case 2 . A $2^{\circ}$ macular sparing together with an irregular ( 1 to $3^{\circ}$ ) paramedial strip of overshot field could be observed in the right eye of case 1 and a spared upper sector of about $5^{\circ}$ in the right eye of case 2 (Fig. 2).

Patients with postgeniculate lesions. All the 5 patients with unilateral damage of the geniculostriate pathway had a dense and virtually complete lateral homonymous hemianopia on $90^{\circ}$ kinetic perimetry. On the $30^{\circ}$ kinetic and static perimetry (Figs. 3 and 4) a variable extent of spared central field could be observed in all 5 cases. This comprised between 0.5 and 1.5 in cases 3 and 4 and between 4 and $6^{\circ}$ in cases 5,6 , and 7 . But, in accordance with 

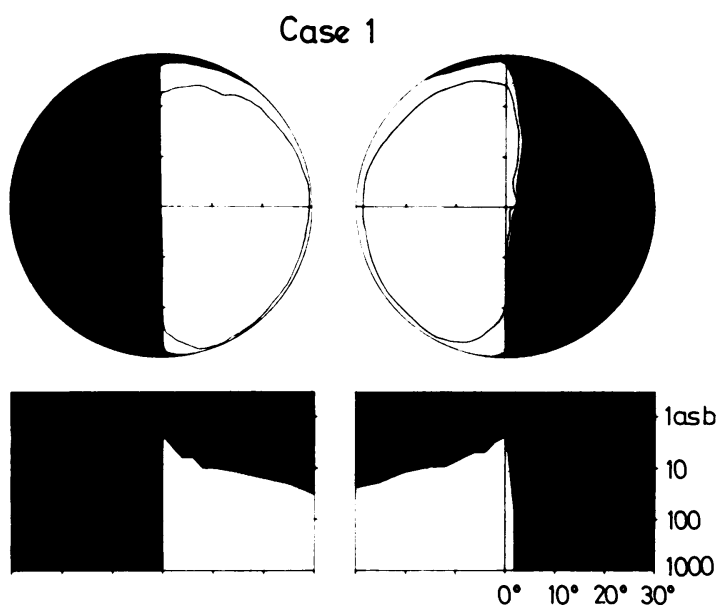

Case 2
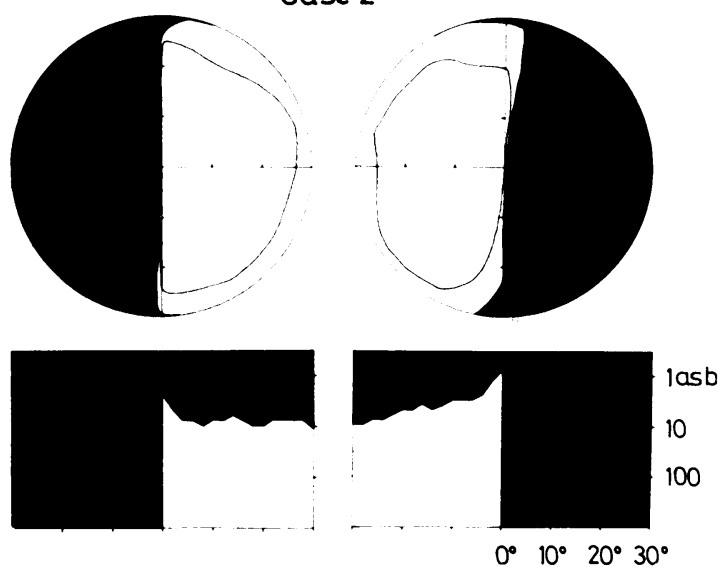

Fig. 2 Visual fields of the 2 subjects (cases 1 and 2) with lesions of the optic chiasma. Background luminance: 10 asb Target size: $10^{\prime}$. For each subject, upper part: $30^{\circ}$ kinetic perimetry with 2 different target luminances (1000 and 32 asb), lower part: $30^{\circ}$ static perimetry along the horizontal meridian.

previous data from static perimetry, ${ }^{822}$ the spared portion of the macular field on the hemianopic side always showed a lower sensitivity than the symmetrical portion within the normal field.

The separation line between the normal and the hemianopic field rarely followed exactly the vertical meridian as it did in case 3's left eye. In most cases the separation line in the periphery moved more or less away from the vertical meridian. Various forms and sizes of overshot field were observed: a $0 \cdot 5^{\circ}$ to $1.5^{\circ}$ strip in case 4 , a sector of about $5^{\circ}$ in the inferior quadrant of the right eye of case 3 , a wider strip of $2^{\circ}$ to $4^{\prime}$ in cases 5,6 , and 7 . In the 3 latter cases unstable fixation which tended to shift the gaze toward the hemianopic side might have been responsible for this effect. It should be noted, however, that the highest sensitivity on profile perimetry always coincided with the centre of fixation, thus ruling out the possibility of a stable eccentric fixation as would be produced by the formation of a 'pseudofovea.'

\section{PERCEPTION OF HAIDINGER BRUSHES}

Patients with pregeniculate lesions. In the 2 patients with a lesion of the optic chiasma only half of the Haidinger figure could be seen with the eye showing a clear macular splitting on static and kinetic perimetry, i.e., the left eye for both patients. One

\section{Case 3}
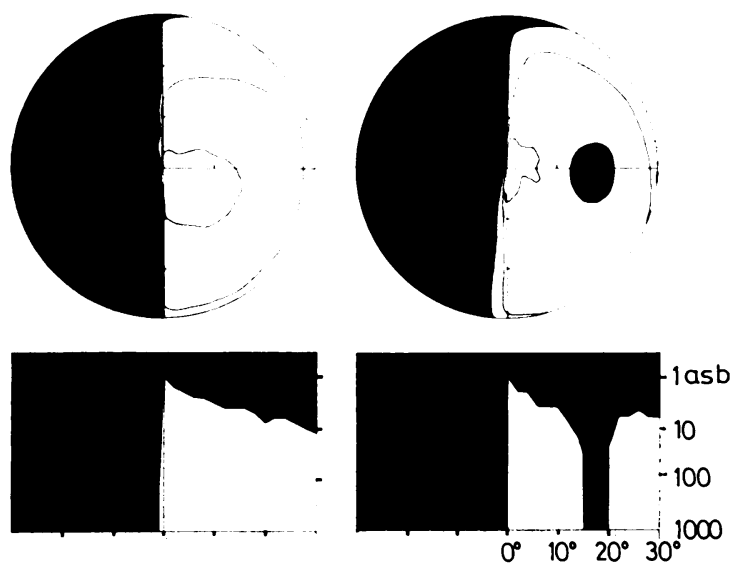

Case 4
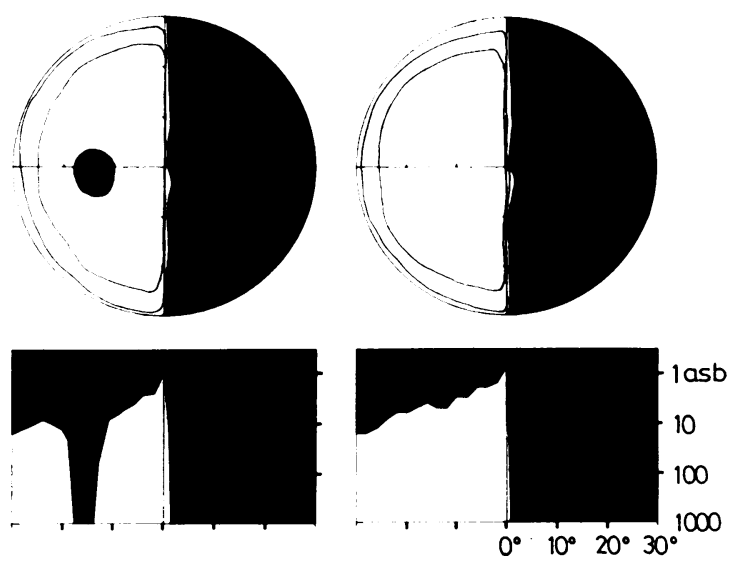

Fig. 3 Visual fields of 2 subjects (cases 3 and 4) with geniculostriate lesions. Same legend as Fig. 2. An additional isoptre has been mapped with respectively 6.3 and 10 asb target luminance for cases 3 and 4. 

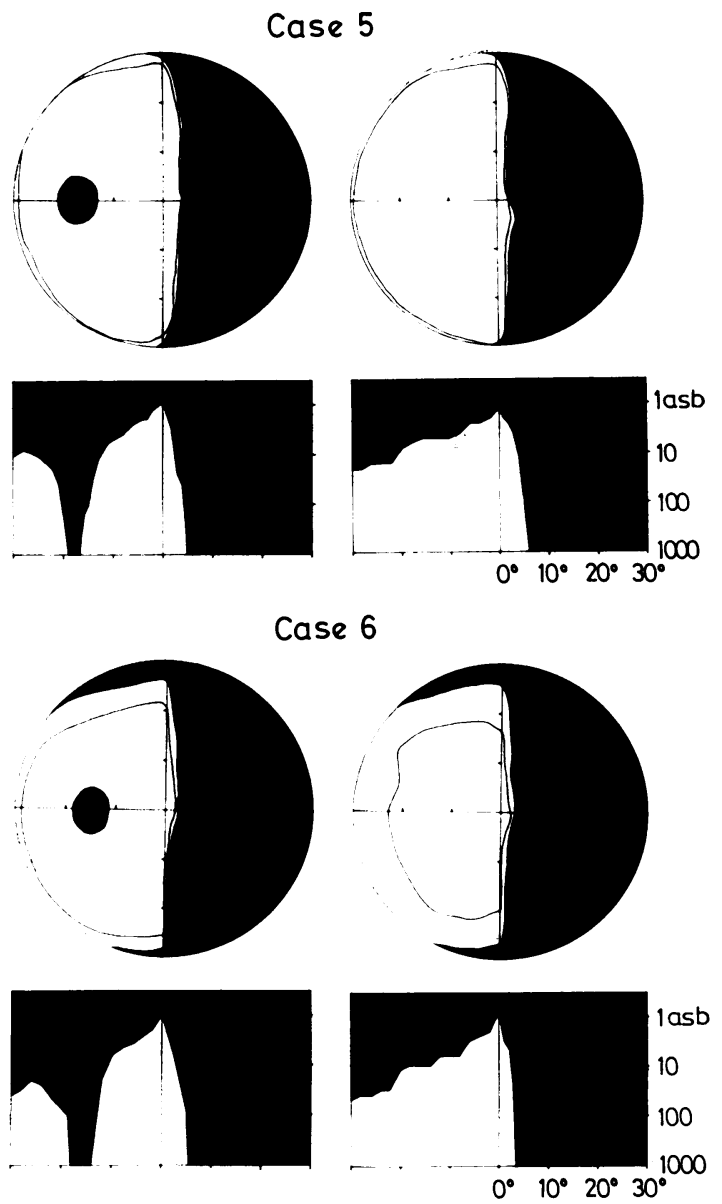

Case 7
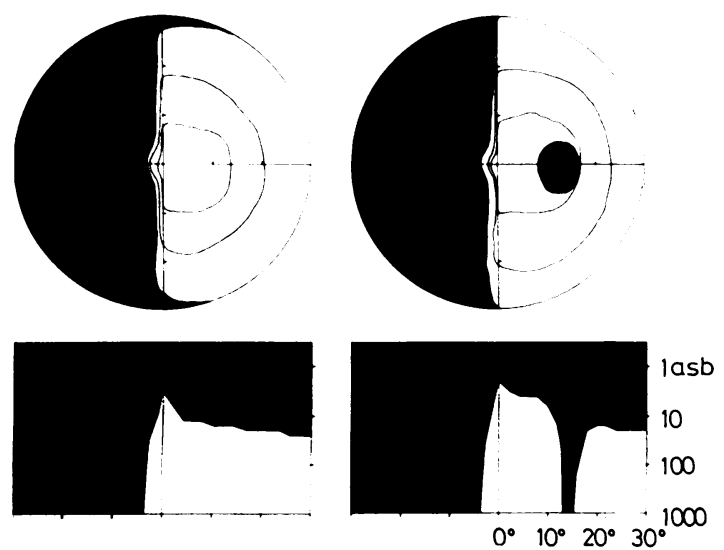

Fig. 4 Visual fields of 3 subjects (cases 5, 6, and 7) with geniculostriate lesions. Same legend as Fig. 2 An additional isoptre has been mapped with a 16 asb target luminance for case 7 . 'brush' was thus seen periodically rotating round its small end point on the right of the fixation axis and then fading out at the vertical meridian. A larger part, though not the whole figure, was perceived with the other eye, showing a $2^{\circ}$ macular sparing in case 1 and a preserved $5^{\circ}$ upper sector in case 2 . When the temporal field was masked, both patients could still discriminate half of the figure with either eye, whereas in most instances it entirely disappeared when the nasal field was masked.

Patients with postgeniculate lesions. Clear, unambiguous responses were obtained from all 5 subjects with geniculostriate lesions. They all perceived, with either eye, the entire Haidinger figure, that is, a symmetrical propeller or hourglass rotating around its centre. Also remarkable was the fact that they all reported a distinctly different picture when the hemianopic field was masked. In all cases but one only half of the figure remained visible, turning around its small end point. In the last case (case 7, right eye only) the figure entirely disappeared in this condition. This may be due to the abnormal position (slight convergent strabismus) of the right eye of this subject. Masking the normal part of the visual field led instead to more variable and sometimes rather surprising effects. Either half of the figure was still perceived, as in case 3 and usually in case 4 or even the whole of it as in the 3 other cases, 5, 6, and 7 . This effect, which at first might seem paradoxical, could be due to a tendency to shift the visual axis towards the hemianopic side in these 3 patients. Consequently the normal field would actually not be entirely covered by the mask, thus allowing the whole foveal area to be exposed to the polarised light.

\section{Discussion}

USEFULNESS OF HAIDINGER BRUSHES FOR

DIFFERENTIATING MACULAR SPARING

AND SPLITTING

Perception of the Haidinger brushes was very different for the 2 types of patients. The 2 subjects with the chiasmatic lesion never reported seeing a whole, symmetrical figure, but only half or a little more of it, in accordance with a previous observation by Fisher et al. ${ }^{12}$ In contrast, the 5 subjects with lesions of the geniculostriate pathway always perceived (in the free gaze situation) an entire, symmetrical picture. This was the case even when the spared central field was as little as $1^{\circ}$ (or less) on perimetric testing, as in cases 3 and 4 (right eye). Subjective responses reported in the postgeniculate group cannot be related to some cognitive factors, such as 'imaginative' completion, ${ }^{23}$ since masking the hemianopic field resulted in only half the figure being perceived. Thus for the Haidinger brushes to be seen entirely 
implies that the 2 foveal half-fields should be exposed to the polarised light, as can be verified in normal subjects.

There was generally a good correlation between the subjective responses to Haidinger brushes and the perimetric data, that is, perception of half the figure corresponded to macular splitting and perception of the whole figure to macular sparing. However, if we remember that Haidinger brushes subtend about $3^{\circ}$ of visual angle i.e., $1.5^{\circ}$ on each side of the visual axis, some discrepancies arise. Thus case 1 could not see the entire figure with his right eye despite a $2^{\circ}$ macular sparing. On the other hand cases 3 and 4 perceived a whole, symmetrical figure despite less than $1^{\circ}$ macular sparing (or no sparing at all on static perimetry of the right eye of case 3 ). In our opinion such discrepancies may reflect the limits of the precision of the perimetric technique, which are due either to small, undetectable shifts of gaze fixation or to released attention of the subject for juxtaliminal stimuli in longstanding examinations.

Consistent results were obtained with the Haidinger brushes in the postgeniculate group. Taking into account the extent of the lesions. (including porencephalic occipital malformation, and hemidecortications) in our sample, it is clear that total exclusion of the visual cortex on one side leaves some spared central vision about $1.5^{\circ}$ width on the contralateral field. This is in agreement with Huber's conclusions, ${ }^{7}$ though he generally found smaller sparing. With regard to the classical opinion (generally admitted, but not always verified by perimetry ${ }^{2}$ ) that macular sparing indicates a postgeniculate lesion and macular splitting a pregeniculate lesion, our results on the 2 patients with damaged optic chiasma provide further data. Similar studies with either optic tract lesions or lesions restricted to the optic radiations would be of interest to this question.

\section{POSSIBLE ANATOMO-FUNCTIONAL}

CORRELATES

The presence or absence of central visual field sparing that we observed respectively after geniculostriate and chiasmatic damage allows us to make anatomical and functional speculations.

Among the numerous hypotheses that have been proposed with respect to macular sparing perhaps the most debated one has been the bilateral representation of the macula on the visual cortex. This hypothesis has been strongly refuted by Spalding, ${ }^{5}$ who pointed out that occipital lesions may result in macular splitting and that, even in the case of restricted lesions, small scotomata may extend to the fixation point. In fact, as in the 2 similar observations reported by Teuber et $a{ }^{6}{ }^{6}$ and Koerner and Teuber, ${ }^{8}$ it may be noted that such scotomata are very often combined with another defect in the contralateral visual field. As those authors suggest, such observations raise the hypothesis of a postgeniculate crossing of 'macular' fibres, possibly through the corpus callosum, which was one of the first formulations of the theory of the double macular representation. ${ }^{24}$

Although such a hypothesis may provide a straightforward explanation of the difference between pre- and postgeniculate lesions, there are several reasons why it is no longer tenable. First, macular sparing is still observed after occipital lobectomy and even hemispherectomy. Secondly, anatomical studies in monkeys have consistently failed to show any crossed geniculostriate connections, either by degeneration methods ${ }^{25}$ or the horseradish peroxidase tracing technique (Garey, personal communication). Instead, the theory of "chessboard innervation of the macula' originally postulated by Morax $^{11}$ has recently regained much interest. In the monkey's retina, ipsi- and contralateral projecting areas overlap along a vertically orientated median strip, about $1^{\circ}$ width, which is centered on the fovea. This was demonstrated by both patterns of either retrograde degeneration of the ganglion cells following unilateral section of the optic tract ${ }^{9}$ or labelling of these cells after horseradish peroxidase (HRP) injection in the dorsal lateral geniculate nucleus. ${ }^{10}$ The latter authors observed that the strip enlarges in two $0.5^{\circ}$ arcs around the unlabelled fovea, though in a very asymmetrical manner with regard to the number of labelled ganglion cells. They suggest that such nasotemporal overlap might provide an anatomical basis for the small central sparing still found in patients with occipital lobectomy. Wyat $\mathrm{t}^{26}$ attempted a more precise estimate of the outline of the bilaterally represented field, taking into account the density of the overlapping ganglion cells (as observed by Bunt et al. ${ }^{10}$ ) together with their receptive field size. The overlap area would be at most $1.5^{\circ}$ width along the horizontal meridian and not particularly convex around the fovea, as in fact the width might increase above and below the fovea, in agreement with some perimetric findings. ${ }^{72}$

However, dual representation of the visual midline, which probably exists in man as it does in the monkey, leaves some remaining facts unexplained. First, splitting of the macula after pregeniculate lesions, and especially chiasmatic lesions as observed in 2 of our patients, does not accord with such nasotemporal overlap, unless some particular arrangement of the overlapping retinogeniculate fibres in the optic chiasma makes them more vulnerable to a lesion at this level. Secondly, the functional consequences which could be expected from dual representation of the visual midline are 
mostly lacking. For example, experiments on choice reaction times show that a difference between crossed and uncrossed conditions is still present when targets appear as close as $15^{\prime}$ to $30^{\prime}$ to the fixation point. 2829

How to reconcile these apparently conflicting facts? Colenbrander ${ }^{30}$ has proposed that the visual midline is bilaterally represented in man but that neurons representing the 'wrong' side of the midline in one occipital cortex are inhibited by corresponding neurons in the other (influenced themselves by brainstem reticular neurons acting at the level of the optic radiations). This could explain the fact that, when the visual cortex or the optic radiations are damaged on one side (but not when retinogeniculate fibres are damaged), the visual cortical neurons on the other side are released from inhibition, with resulting macular sparing. However, this remains to be proved.

If the median visual field, which is bilaterally represented, has the same width in man as in the monkey (i.e., at most $1 \cdot 5^{\circ}{ }^{26}$ ) this would not be enough to account for the fact that our patients with postgeniculate lesions could perceive a whole symmetrical Haidinger figure of about $3^{\circ}$ diameter. An additional factor might be represented by completion of the figure in a manner similar to that observed by Torjussen, ${ }^{31}$ when both intact and hemianopic hemifields are stimulated. This author proposed that completion of this type might be related to residual vision in the hemianopic field and mediated by spared midbrain structures. The recent demonstration of important direct projections from the fovea to the colliculus in the monkey ${ }^{32}$ makes such a hypothesis relevant to the perception of Haidinger brushes in patients with geniculostriate lesions.

\section{References}

1 Williams D, Gassel MM. Visual function in patients with homonymous hemianopia. Part I: the visual fields. Brain 1962; 85: 175-250.

2 Walsh FB, Hoyt WF. Clinical Neuro-opthalmology. Baltimore: Williams and Wilkins, 1969.

3 Allen IM. A clinical study of tumours involving the occipital lobe. Brain 1930; 53: 194-243.

4 Horrax G, Putman TJ. The field defects and hallucinations produced by tumours of the occipital lobe. Brain 1932; 55: 499-523.

5 Spalding JMK. Wounds of the visual pathway. Part II: the striate cortex. J Neurol Neurosurg Psychiatry 1952; 15: 169-83.

6 Teuber HL, Battersby WS, Bender MB. Visual Fields Defects after Penetrating Missile Wounds of the Brain. Cambridge: Harvard University Press, 1960.

7 Huber A. Homonymous hemianopsia after removal of one occipital lobe. Acta Conc Ophthal Mexico 1971; 2: 1333-8.

8 Koerner F, Teuber HL. Visual field defects after missile injuries to the geniculo-striate pathway in man. Exp Brain Res 1973; 18: 88-113.

9 Stone J, Leicester L, Sherman SA. The naso temporal division of the monkey's retina. J Comp Neurol 1973; 150: 333-48.

10 Bunt AH, Winkler DS, Johanson GW. Demonstration of bilateral projection of central retina of monkey with horseradish peroxidase neuronography. J Comp Neurol 1977; 171 : 619-80.

11 Morax V. Discussion des hypothèses faites sur les connexions corticales des faisceaux maculaires. Ann Oculist (Paris) 1919; 156: 25.

12 Fisher NF, Jampolsky A, Scott AB. Traumatic bitemporal hemianopsia. Part I: Diagnostic of macular splitting. $\mathbf{A m}$ J Ophthalmol 1968; 65: 237-42.

13 Vadot E, Perenin MT. L'épargne maculaire dans les hémianopsies latérales homonymes d'origine occipitale: étude au moyen des houppes de Haidinger. Bull Soc Ophtalmol Fr 1979; 79: 653-6.

14 Perenin MT, Jeannerod M. Visual function within the hemianopic field following early cerebral hemidecortication in man. I: spatial localization. Neuropsychologia 1978; 16: 1-13.

15 Perenin MT. Visual function within the hemianopic field following early cerebral hemidecortication in man. II: pattern discrimination. Neuropsychologia 1978; 16: 697-708.

16 Sloan LL. The Tübingen perimeter of Harms and Aulhorn. Arch Ophthalmol 1971; 86: 612-22. Aulhorn E, Harms H. Visual perimetry. In: Jameson D, 17 Hurvich LM, eds. Handbook of Sensory Physiology. Berlin: Springer, 1972; 7: 102.

18 Haidinger W. Uber das direkte Erkennen des polarisierten Lichts. Poggendorffs Ann 1844; 63: 29.

19 Rodieck RW. The Vertebrate Retina. Principles of Structure and Function. San Francisco: Freeman, 1973.

20 Walker J. Studying polarized light with quarter-wave and half-wave plates of one's own making. Scientific Am 1977; 237: 172-80.

21 Hochheimer BF. Polarized light retinal photography of a monkey eye. Vision Res 1978; 18: 19-23.

22 Harms H, Raabe M. Besondere perimetrische Methoden bei ophthalmoneurologische Erkrankungen Osterr Ophthal Ges 1960; 5: 1-13.

23 Poppelreuter W. Die psychischen Schädigungen durch Kopfschuss im Kriege 1914-16 die Störungen der niederen und höheren Schleistungen durch Verletezungen des Okzipitalhirns. Leipzig: Voss, 1917.

24 Penfield W, Evans JP, McMillan JA. Visual pathways in man with particular reference to macular representation. Arch Neurol 1935; 13: 816-34.

25 Polyak S. In: Klüver $\mathrm{H}$, ed. The Vertebrate Visual System: Chicago: University of Chicago Press, 1957.

26 Wyatt HJ. Nasotemporal overlap and visual field sparing. Invest Ophthalmol Visual Sci 1978; 17: 1128-30.

27 Dubois-Poulson A. Le Champ Visuel. Paris: Masson, 1952: 983-1007.

28 Harvey LO. Single representation of the visual midline in humans. Neuropsychologia 1978; 16: 601-10.

29 Haun F. Functional dissociation of the hemispheres using foveal visual input. Neuropsychologia 1978; 16: 725-34.

30 Colenbrander MC. Sparing of the macula. Ophthalmologica 1975 ; 171 : $91-4$.

31 Torjussen $\mathrm{T}$. Visual processing in cortically blind hemifields. Neuropsychologia 1978; 16: 15-21.

32 Cowey A, Perry VH. The projection of the fovea to the superior colliculus in rhesus monkeys. Neuroscience 1980; 5: 53-61. 